\title{
From basic molecular biology to curative antiviral therapy: the success story of Hepatitis C virology
}

\author{
Matthias J. Reddehase ${ }^{1}$
}

Published online: 17 October 2018

c) Springer-Verlag GmbH Germany, part of Springer Nature 2018

On May 16, 2018, scientific companions and friends from all over the world gathered to honor Ralf Bartenschlager (Fig. 1) with the Ralf Bartenschlager's 60th Birthday Symposium in Heidelberg, Germany, organized and chaired by his congenial scientific partner for decades: Volker Lohmann. Ralf Bartenschlager is currently in a joint position 'Executive Director of the Department of Molecular Virology' at the Center for Infectious Diseases at Heidelberg University Hospital and Faculty of Medicine (Chica and Heinz Schaller Foundation Professorship) since 2002 and 'Research Director for Infection, Inflammation, and Cancer' at the German Cancer Research Center since 2014.

It is no mere compliment to say that Ralf Bartenschlager is in the upper top list of the internationally most renowned and most highly decorated virologists and of German scientists in general, showered with awards for his outstanding scientific achievements. I refrain here from listing all of them, as nothing compares to the Lasker-DeBakey Clinical Medical Research Award dedicated in 2016 to the Hepatitis C Replicon System and Drug Development, honoring him along with his colleagues Charles M. Rice (Rockefeller University, New York) and Michael J. Sofia (Arbutus Biopharma), who in cooperation and fruitful competition developed a system to study the replication of the Hepatitis $\mathrm{C}$ virus genome in cell culture. These studies led to the identification of molecular targets of antiviral drugs that eventually turned out to have revolutionized the medical treatment of chronic Hepatitis C. Of the four categories of Lasker Awards (http://www.laske rfoundation.org/awards-overview/ and http://www.laske rfoundation.org/awards/show/hepatitis-c-replicon-syste

This Editorial refers to the review article available at https://doi. org/10.1007/s00430-018-0566-x.

Matthias J. Reddehase

matthias.reddehase@uni-mainz.de

1 Institute for Virology, University Medical Center of the Johannes Gutenberg University Mainz and Research Center for Immunotherapy, Mainz, Germany m-and-drug-development/\#video), awarded annually by the Lasker foundation and considered the 'unofficial American Nobel Prize of Medicine', the Lasker-DeBakey Clinical Medical Research Award is dedicated to a major advance in medicine that improves the lives of many thousands of people.

Linking Ralf Bartenschlager to Robert Koch, laureate of the Nobel Prize in Physiology or Medicine 1905 and founding editor of 'Medical Microbiology and Immunology' in 1886 under the journal's previous name 'Zeitschrift für Hygiene', Ralf Bartenschlager, in earlier days of his outstanding career, was encouraged by receiving the Robert Koch Research Fellow Award 2000 of Clausthal-Zellerfeld, an old ore mining city in the German Harz mountains, the place where Robert Koch was born. In a follow-up honor in Robert Koch's footsteps, Ralf Bartenschlager received the highly esteemed Robert Koch Award of the 'Robert Koch Foundation' in 2015, jointly with his colleague Charles M. Rice. I am therefore a bit proud that Ralf Bartenschlager accepted my invitation to serve as an Editor of Medical Microbiology and Immunology, being responsible for the topic of viral hepatitis (https://www.springer.com/430 and https://www.springer.com/430/PSE?detailsPage=press).

Every success in science has its roots. The deepest scientific root of Ralf Bartenschlager, who did not study medicine but biology at the University of Heidelberg, undoubtedly was his mentor Heinz Schaller, from whom he received top-of-the-world training in hard-core molecular genetics, providing him with essential technical skills and with the expertise to develop the Hepatitis $\mathrm{C}$ replicon system years later. After an interim gaining experience and 'translational thinking' in pharmaceutical research at Hoffmann-La Roche in Basel, Switzerland, Ralf joined me in 1994 to build up the newly founded 'Institute for Virology' at the University Medical Center of the Johannes Gutenberg-University Mainz, for which I was - and still am-the founding director. It was my privilege and pleasure to witness the earliest steps in the development of the prototype Hepatitis $\mathrm{C}$ 
Fig. 1 Ralf Bartenschlager, proudly enjoying to listen to the laudations given by friends, alumni, and colleagues at the Ralf Bartenschlager's 60th Birthday Symposium in Heidelberg, Germany, on May 16, 2018. Photograph by courtesy of Volker Lohmann

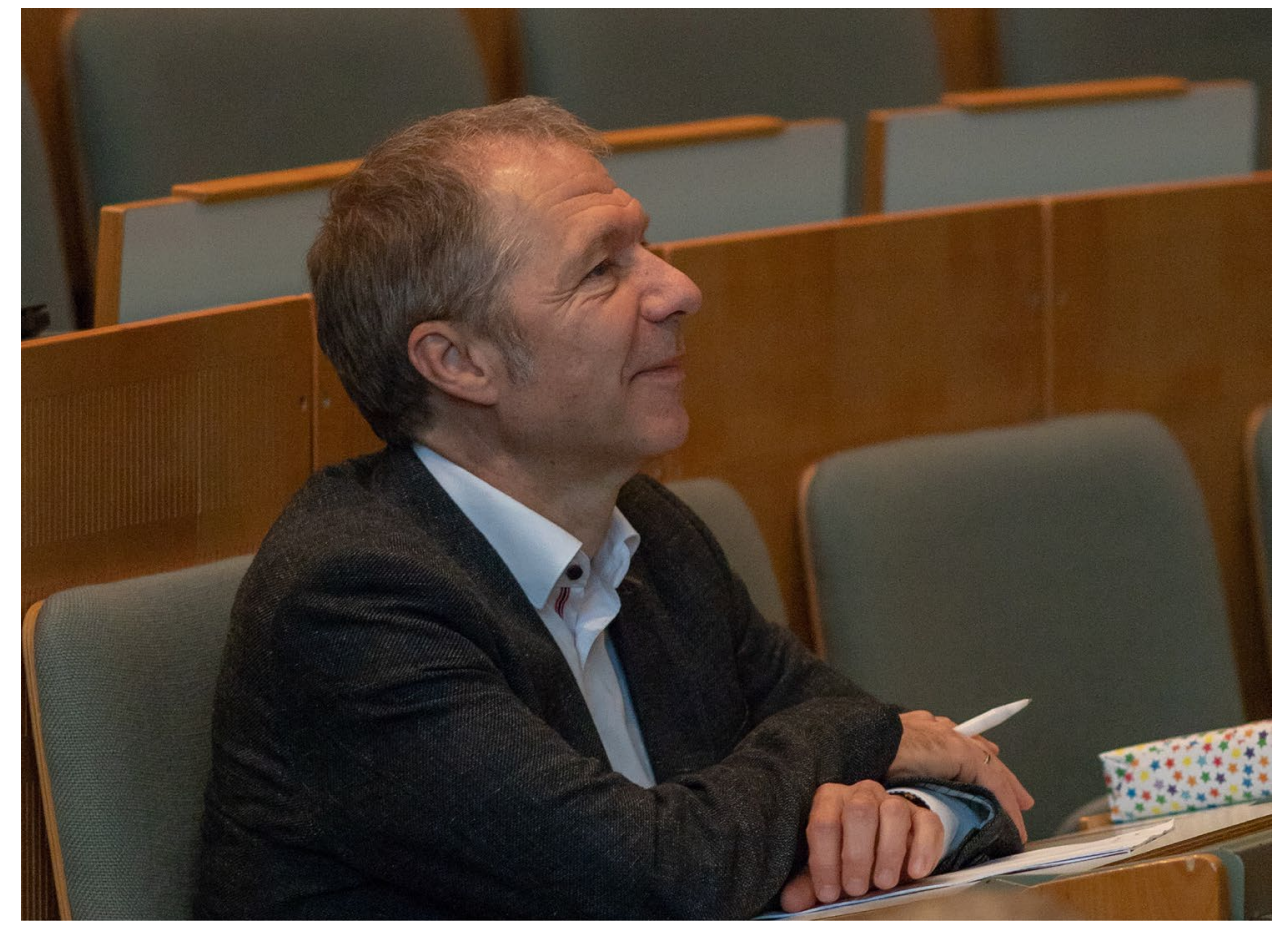

replicon by Ralf's scientific team, including the young and promising doctoral student Volker Lohmann, in our institute's weekly progress report seminars. I must say, I somehow felt in these early days that 'something great' is going to come, but, admittedly, neither I nor, probably, Ralf himself could predict that this work would so soon lead to a curative antiviral therapy of Hepatitis C. This is a splendid example of how basic science, conducted by biologists, can result in a major progress in medicine to the benefit of patients.

In this issue of Medical Microbiology and Immunology [1], Volker Lohmann reviews the generation of the prototype Hepatitis C replicon in Mainz, culminating in the pioneering publication in the journal Science [2], as well as of subsequent generations of advanced replicons that provided the basis for antiviral therapy of Hepatitis C.
Matthias J. Reddehase

Editor-in-Chief for Virology, Medical Microbiology and Immunology

\section{References}

1. Lohmann V (2018) Hepatitis C virus cell culture models: an encomium on basic research paving the road to therapy development. Med Microbiol Immunol. https://doi.org/10.1007/s0043 0-018-0566-x

2. Lohmann V, Körner F, Koch J, Herian U, Theilmann L, Bartenschlager R (1999) Replication of subgenomic hepatitis C virus RNAs in a hepatoma cell line. Science 285:110-113 